\title{
Middle Cambrian gogiid echinoderms from Northeast Spain: Taxonomy, palaeoecology, and palaeogeographic implications
}

Samuel Zamora, Rodolfo Gozalo, and Eladio Liñán

Acta Palaeontologica Polonica 54 (2), 2009: 253-265 doi:http://dx.doi.org/10.4202/app.2008.0010

Gogia parsleyi Zamora sp. nov. and Gogia sp. are described from two different echinoderm assemblages, both from the middle Cambrian of the Murero Formation (Iberian Chains, NE Spain). Gogia parsleyi is reconstructed and described on the basis of fifteen complete or partial specimens and numerous isolated plates. It is characterised by spiralled brachioles, simple epispires, sometimes covered by stereomic domes or tiny cover plates, and by thecal plates arranged in subregular circlets. This gogiid population comprises juveniles, advanced juveniles and mature individuals. The material was found in the upper part of the Murero Formation (upper Caesaraugustian-lower Languedocian). Gogia sp. is represented by two almost complete specimens and several isolated plates from the lower part of the Murero Formation (lower Caesaraugustian). The genus Gogia was first described in Western Gondwana from the Languedocian (upper middle Cambrian) of France, but the material from Spain is older and represents the oldest record of this genus in Gondwana, suggesting an early migration from Laurentia. The gogiids are well preserved in two echinoderm Lagerstätten, which, together with other echinoderms, comprise the majority of the fossil fauna. Both levels are derived from obrution deposits produced in calm and open marine conditions, sometimes affected by sporadic storms. Their holdfast morphology suggests that these gogiids were low-tier suspension feeders, living attached to trilobite fragments in a soft, muddy environment.

Key words: Echinodermata, Eocrinoidea, Gogiida, Cambrian, Murero Formation, Spain.

Samuel Zamora [samuel@unizar.es] and Eladio Liñán [linan@unizar.es]. Área y Museo de Paleontología, Departamento de Ciencias de la Tierra, Universidad de Zaragoza, E-50009 Zaragoza, Spain; Rodolfo Gozalo [Rodolfo.Gozalo@uv.es], Departamento de Geología. Universitat de València.C/ Dr. Loliner n50. E-46100 Burjasot (Valencia), Spain.

This is an open-access article distributed under the terms of the Creative Commons Attribution License (for details please see creativecommons.org), which permits unrestricted use, distribution, and reproduction in any medium, provided the original author and source are credited. 
FoF Full text $(1,490.2 \mathrm{kB})$ 